\title{
PEMBERDAYAAN PAGUYUBAN “SEMAR CAKEP” DALAM UPAYA PERAWATAN ANAK PENYANDANG DISABILITAS MASA PANDEMI COVID-19
}

DOI: https://doi.org/10.33024/jkpm.v4i5.4182

\author{
Dyah Restuning Prihati ${ }^{*}$, Endang Supriyanti ${ }^{2}$ \\ 1-2 Universitas Widya Husada Semarang \\ Disubmit: 07 April 2021 Diterima: 08 Mei 2021 Diterbitkan: 30 September 2021 \\ *Email korespendensi: dyah.erpe@gmail.com
}

\begin{abstract}
ABSTRAK
Anak dengan penyandang disabilitas adalah kelompok khusus yang beresiko terpapar COVID-19. Mereka melakukan activity daily living, mobilitas dan komunikasi membutuhkan pendampingan dari orangtua maupun pengasuhnya. Mereka memiliki keterbatasan dalam memahami bagaimana pencegahan penukaran COVID-19. Identifikasi permasalahan yang dihadapi mitra adalah pengetahuan pengurus Paguyuban Peduli Penyandang Disabilitas SEMAR CAKEP tentang perawatan anak penyandang disabilitas di masa pandemi COVID-19 masih kurang dan belum ada penyuluhan tentang perawatan anak penyandang disabilitas di masa pandemi COVID-19 oleh petugas kesehatan. Tujuan kegiatan PKM ini adalah memberdayakan atau pendampingan pengurus Paguyuban Peduli Penyandang Disabilitas SEMAR CAKEP tentang perawatan anak penyandang disabilitas di masa pandemi COVID-19. Metode yang digunakan adalah pendampingan dengan memberikan pengetahuan tentang perawatan anak penyandang disabilitas di masa pandemi COVID-19 dan Masalah nutrisi pada cerebral palsy. Hasil Kegiatan ini terdapat peningkatan pengetahuan sebanyak 10 orang (91\%) dan yang memiliki pengetahuan rendah sebanyak 1 orang (9\%). Peningkatan upaya promotif dan preventif sebagai upaya deteksi dini pencegahan anak penyandang disabilitas terpapar COVID-19. Keberadaan pendamping bagi anak berkebutuhan khusus memiliki makna yang berarti bagi proses perlindungan dan tumbuh kembangnya. Diharapkan dengan implementasi ini, pengurus paguyuban peduli penyandang disabilitas SEMAR CAKEP bisa menerapkan dan memberikan informasi kepada orang tua dalam perawatan anak penyandang disabilitas di masa pandemi COVID-19.
\end{abstract}

Kata Kunci : Paguyuban; Perawatan Anak Disabilitas; COVID-19

\begin{abstract}
Children with disabilities are a special group who are at risk of being exposed to COVID-19. They carry out daily living, mobility and communication activities that require assistance from parents and caregivers. They have limitations in understanding how to prevent the exchange of COVID-19. The identification of problems faced by partners is the knowledge of the Paguyuban Caring for Persons with Disabilities, SEMAR CAKEP management about caring for children with disabilities during the COVID-19 pandemic is still lacking and there has been
\end{abstract}


no counseling about the care of children with disabilities during the COVID-19 pandemic by health workers. The purpose of this PKM activity is to empower or assist the administrators of the SEMAR CAKEP Care for Persons with Disabilities regarding the care of children with disabilities during the COVID-19 pandemic. The method used is assistance by providing knowledge about the care of children with disabilities during the COVID-19 pandemic and nutritional problems in cerebral palsy. The results of this activity there was an increase in knowledge by 10 people (91\%) and 1 person (9\%) who had low knowledge. Increasing promotional and preventive efforts as an effort to prevent children with disabilities from being exposed to COVID-19. The existence of a companion for children with special needs has meaningful meaning for the process of protection and development. It is hoped that with this implementation, the management of the association caring for people with disabilities, SEMAR CAKEP, can apply and provide information to parents in caring for children with disabilities during the COVID-19 pandemic.

Keywords: Association; Care for Children with Disabilities; COVID-19

\section{PENDAHULUAN}

Undang Undang No 8 Tahun 2016 dijelaskan bahwa penyandang disabilitas adalah anak yang mengalami keterbatasan fisik, intelektual, mental, dan/atau sensorik yang memiliki hambatan dan kesulitan untuk melakukan kegiatan sehari-hari. Anak disabilitas termasuk cerebral palsy, spina bifida, down sindrom, dan gangguan pendengaran, visual, fisik,komunikasi dan gangguan intelektual. Indonesia mulai mengalami pandemi Covid-19 pada awal bulan Maret 2020 yang mengakibatkan perubahan berbagai aspek kehidupan. Pemberlakuan protokol kesehatan salah satunya social and physical distancing, bekerja, beribadah dan belajar dari rumah juga turut mempengaruhi gaya hidup seluruh masyarakat. Anak dengan penyandang disabilitas adalah kelompok khusus yang beresiko terpapar COVID-19. Mereka melakukan activity daily living, mobilitas dan komunikasi membutuhkan pendampingan dari orangtua maupun pendampingnya. Mereka memiliki keterbatasan dalam memahami bagaimana pencegahan penukaran COVID-19. Keberadaan orang tua atau pendamping bagi anak berkebutuhan khusus memiliki peranan yang penting untuk proses perlindungan dan tumbuh kembangnya (Kementerian Pemberdayaan Perempuan dan Perlindungan Anak, 2013). Peran dari orang tua atau pengasuh anak dengan penyandang disabilitas, akan mencegah resiko terpapar COVID-19.

Dampak pandemi COVID-19 dirasakan penyandang disabilitas yaitu adanya keterbatasan akses untuk mendapatkan pelayanan publik menghambat penyandang disabilitas untuk mendapatkan pelayanan kesehatan (Quyumi \& Alimansur, 2020). Kondisi pandemi COVID-19 yang membuat anak penyandang disabilitas tinggal di dalam rumah dan membatasi aktivitas di luar. Anak penyandang disabilitas mempunyai hak untuk mendapatkan pelindungan khusus (Undang-Undang, 2016)(Afifah \& Hadi, 2018). Kurangnya pemahaman terhadap pencegahan dan penularan COVID- 19 menyebabkan ketidakpatuhan masyarakat terhadap protokol kesehatan (Prihati, Wirawati, \& Supriyanti, 2020).

Pada bulan mei 2018 telah di siapkan ruangan untuk ruang belajar ABK cerebal palsy di kantor kecamatan Semarang Barat. Pada bulan Juli 2019 
telah diresmikan ruang belajar difabel cerebal palsy Semar Cakep Kecamatan Semarang Barat oleh wali kota Semarang. Saat ini ruang belajar Semar Cakep terdapat sekitar 83 anak dari semarang, kendal, demak, grobogan. Kudus dan salatiga. Kegiatan rutin belajar hari senin - kamis, namun saat kondisi pandemi kegiatan belajar mengajar sementara tidak dilakukan. Hasil wawancara dengan ketua paguyuban, saat ini pengurus paguyuban aktif dalam melakukan kegiatan pembelajaran di Semar Cakep dalam bentuk edukasi permainan, menyanyi. Paguyuban Semar Cakep telah mendirikan Puskesmas Mandiri, adapun kegiatan yang dilakukan adalah pengukuran tinggi badan, berat badan LILA, LIKA. Kegiatan posyandu mandiri dilakukan tiap bulan dengan pendampingan dari puskesmas karang ayu. Selama pandemi ini kegiatan posyandu mandiri tidak ada, ABK mngukur tinggi badan, berat badan, LILA,LIKA dari rumah untuk dilaporkan ke pengurus paguyuban SEMAR CAKEP lewat whatsapp. Saat ini pengurus paguyuban Semar Cakep merasa belum maksimal dalam melaksanakan pendampingan, karena tidak pernah melakukan perawatan anak penyandang disabilitas di masa pandemi ini. Para pengurus berharap ada pelatihan tentang kesehatan yang dilakukan oleh tenaga kesehatan untuk meningkatkan pengetahuan mereka terkait kesehatan khususnya ABK.

Program Kemitraan Masyarakat diberikan kepada pengurus Paguyuban Peduli Penyandang Disabilitas SEMAR CAKEP Semarang Barat, diharapkan dengan mereka mengetahui dan bisa mengaplikasikan tentang perawatan anak penyandang disabilitas di masa pandemi COVID-19. Peningkatan upaya promotif dan preventif sebagai upaya deteksi dini pencegahan anak penyandang disabilitas terpapar COVID-19.

\section{MASALAH}

Identifikasi permasalahan yang dihadapi mitra yaitu pengetahuan pengurus paguyuban peduli penyandang disabilitas "SEMAR CAKEP" tentang perawatan anak penyandang disabilitas di masa pandemi COVID-19 masih kurang dan belum ada penyuluhan tentang perawatan anak penyandang disabilitas di masa pandemi COVID-19 oleh petugas kesehatan, lokasi jarak Universitas Widya Husada dengan mitra dekat.

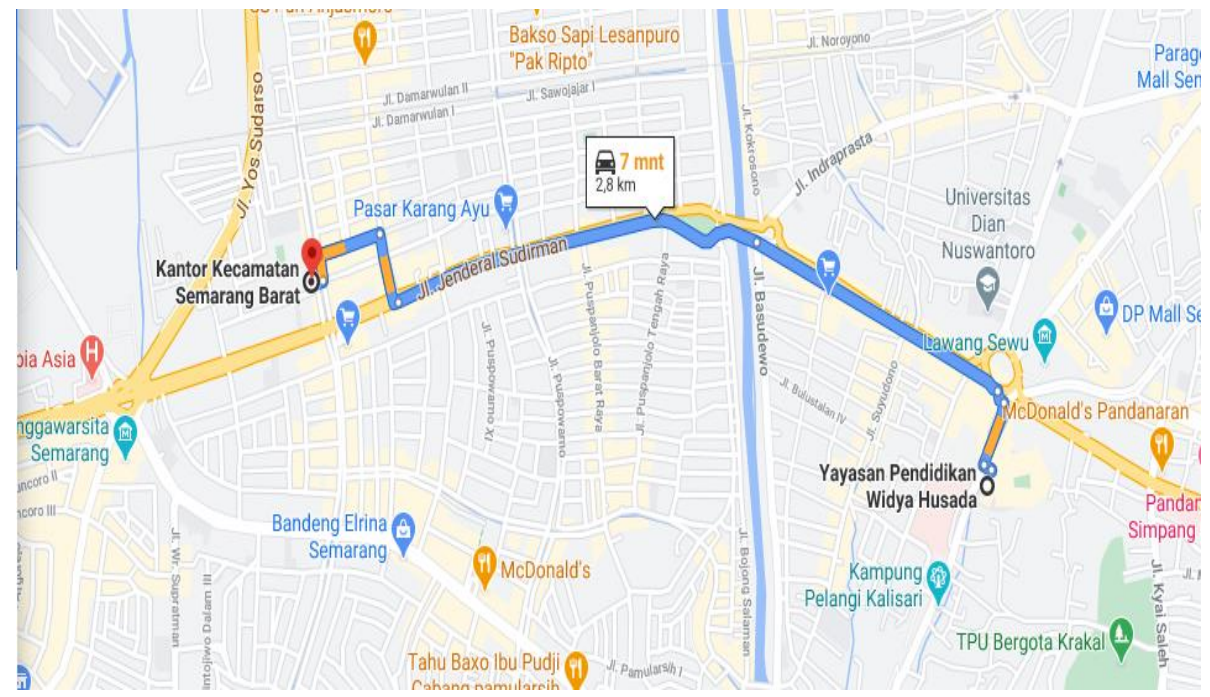

Gambar 2.1 Peta Lokasi Kegiatan Program Kemitraan Masyarakat 


\section{METODE}

a. Persiapan Kegiatan

Persiapan kegiatan dimulai dengan persiapan tempat dan media dipersiapkan sesuai dengan kebutuhan serta antisipasi kemungkinan masalah yang terjadi. Tim Program Kemitraan Masyarakat menyediakan fasilitator selama kegiatan berlangsung. Persiapan dilakukan untuk memulai kegiatan sehingga sesuai dengan sasaran dan tujuan yang diharapkan. Pembuatan booklet perawatan tentang perawatan anak penyandang disabilitas di masa pandemi COVID-19..

b. Pelaksanaan Kegiatan

Pelaksanaan pengabdian akan dilakukan dalam jangka waktu 3 bulan. Kegiatan pelatihan dilaksanakan tanggal 18 Februari 2021 dengan pemberian materi tentang perawatan tentang perawatan anak penyandang disabilitas di masa pandemi COVID-19 serta masalah nutrisi pada cerebral palsy. Alokasi waktu adalah 120 menit. Peserta yang hadir sebanyak 11 orang.

c. Evaluasi Kegiatan

Evaluasi kegiatan dilakukan dengan memberikan kuisioner pengetahuan pada pengurus paguyuban yang mengikuti kegiatan.

\section{HASIL DAN PEMBAHASAN}

Kegiatan Program Kemitraan Masyarakat pemberdayaan paguyuban "SEMAR CAKEP" Semarang Barat dengan pemberian materi tentang perawatan anak penyandang disabilitas di masa pandemi COVID-19 dan demonstrasi cuci tangan serta masalah nutrisi pada cerebral palsy. Tersedianya booklet perawatan tentang perawatan anak penyandang disabilitas di masa pandemi COVID-19. Setelah diberikan materi, pengurus paguyuban "SEMAR CAKEP" yang memiliki pengetahuan tinggi sebanyak 10 orang (91\%) dan yang memiliki pengetahuan rendah sebanyak 1 orang (9\%). Promosikan perilaku hidup bersih dan melakukan cuci tangan secara teratur sebagai bentuk dari protokol kesehatan masa pendemi COVID-19 (DirJend Kementerian Sosial, 2020)

Penyandang disabilitas memiliki keterbatasan dalam aktivitas, hal ini dapat meningkatkan stress, maka dibutuhkan dukungan dari anggota keluarga atau para pengasuhnya yang dapat meningkatkan kontak sosial mereka. Penyandang disabilitas intelektual lebih memungkinkan untuk memiliki kesulitan dalam mengadvokasi diri sendiri dan akan lebih bergantung pada orang lain dalam usahanya untuk menjauhi dari terkena infeksi di masa Pandemi Covid-19 (Courtenay \& Perera, 2020). Berdasarkan penjelasan dari Inter-Agency Standing Committee, penyandang disabilitas mental juga memiliki masalah akibat pandemi Covid-19 ini. Masalah tersebut antara lain masalah lingkungan karena terbatasnya pusat kesehatan yang dapat diakses akibat protokol dari pemerintah yang menghimbau masyarakat untuk tetap tinggal di rumah dan menjaga jarak dengan satu sama lain. Kemudian secara institusional, masalah juga muncul akibat biaya layanan kesehatan yang tinggi dapat menghambat penyandang disabilitas mental untuk mengakses layanan-layanan penting. Selanjutnya, masalah juga datang dari sikap masyarakat yang masih berprasangka buruk dan menstigmakan serta mendiskriminasikan penyandang disabilitas mental yang dapat menimbulkan stres bagi mereka di tengah-tengah wabah Covid-19 ini. Stress yang berlebihan dapat menimbulkan kesehatan mental terganggu 
(Radissa, 2020). Penyuluhan kesehatan merupakan bagian dari pendidikan kesehatan untuk mempengaruhi perilaku kesehatan individu, kelompok maupun masyarakat. Keterbatasan dalam melakukan beberapa aktivitas sehari - hari, menyebabkan anak kesulitan untuk mengontrol dirinya, kehilangan keseimbangan, mudah resiko jatuh (Kusumah, 2017). Pengurus paguyuban peduli penyandang disabilitas memilik peranan penting dalam meningkatkan permasalahan perawatan anak penyandang disabilitas yang dialami oleh keluarga di masa pandemi COVID-19, maka dibutuhkan upaya pemberdayaan pengurus paguyuban peduli penyandang disabilitas dalam peningkatan pengetahuan perawatan anak penyandang disabilitas di wilayah kecamatan Semarang Barat. Saat pelaksanaan kegiatan program kemitraan masyarakat, terlihat motivasi pengurus paguyuban peduli penyandang disabilitas yang begitu antusias bertanya serta keaktifan para peserta paguyuban menunjukkan mereka membutuhkan informasi perawatan anak penyandang disabilitas di masa pandemi COVID-19. Pengalaman merawat anak penyandang disabilitas menjadikan pengurus paguyuban ingin lebih banyak tahu dan memahami peran dan fungsi kader selama perawatan anak penyandang disabilitas. Kurangnya sumber informasi menyebabkan informasi atau pesan yang diterima menjadi kurang yang beerpengaruh pada perilaku sesorang (Sulastri, 2018).

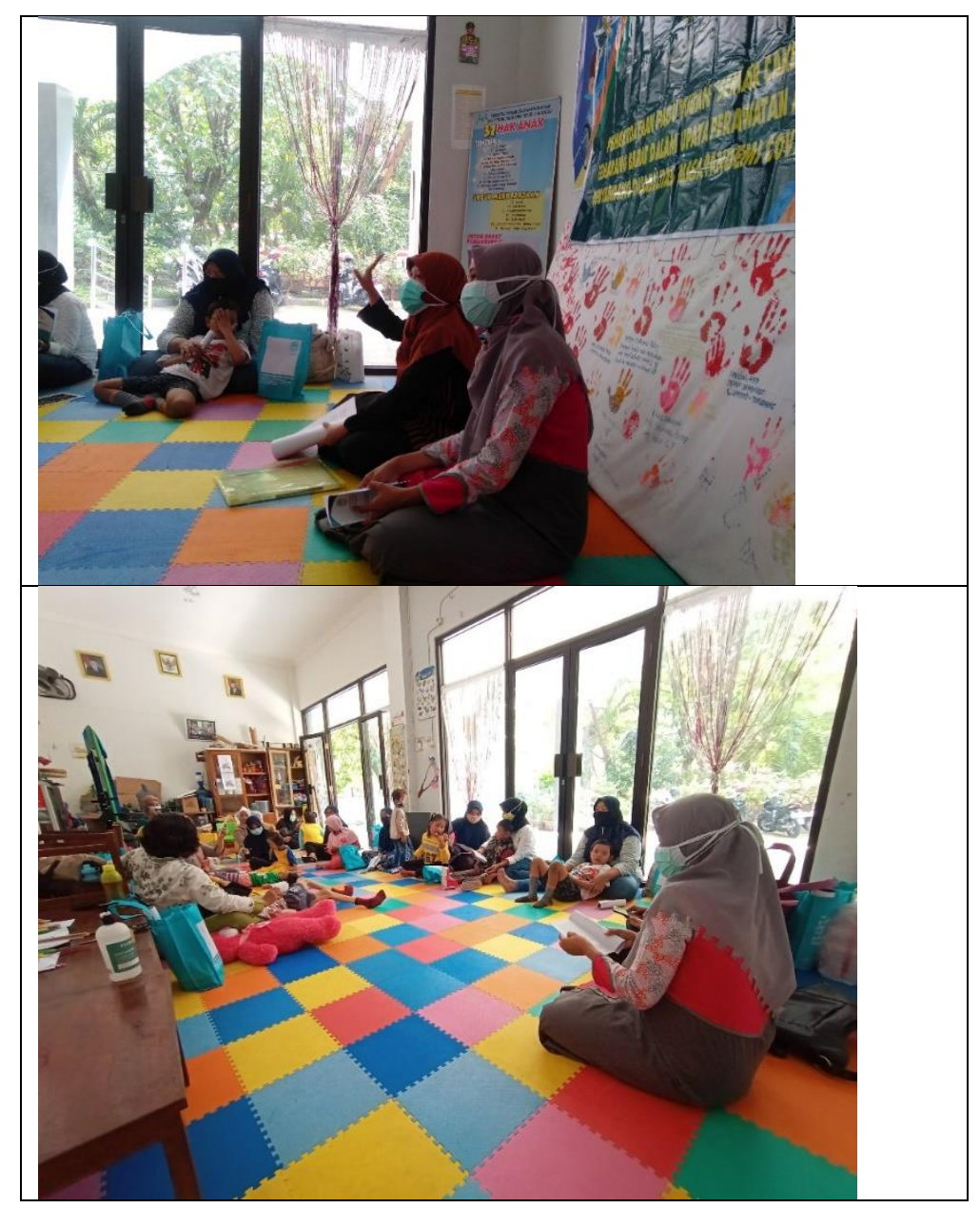




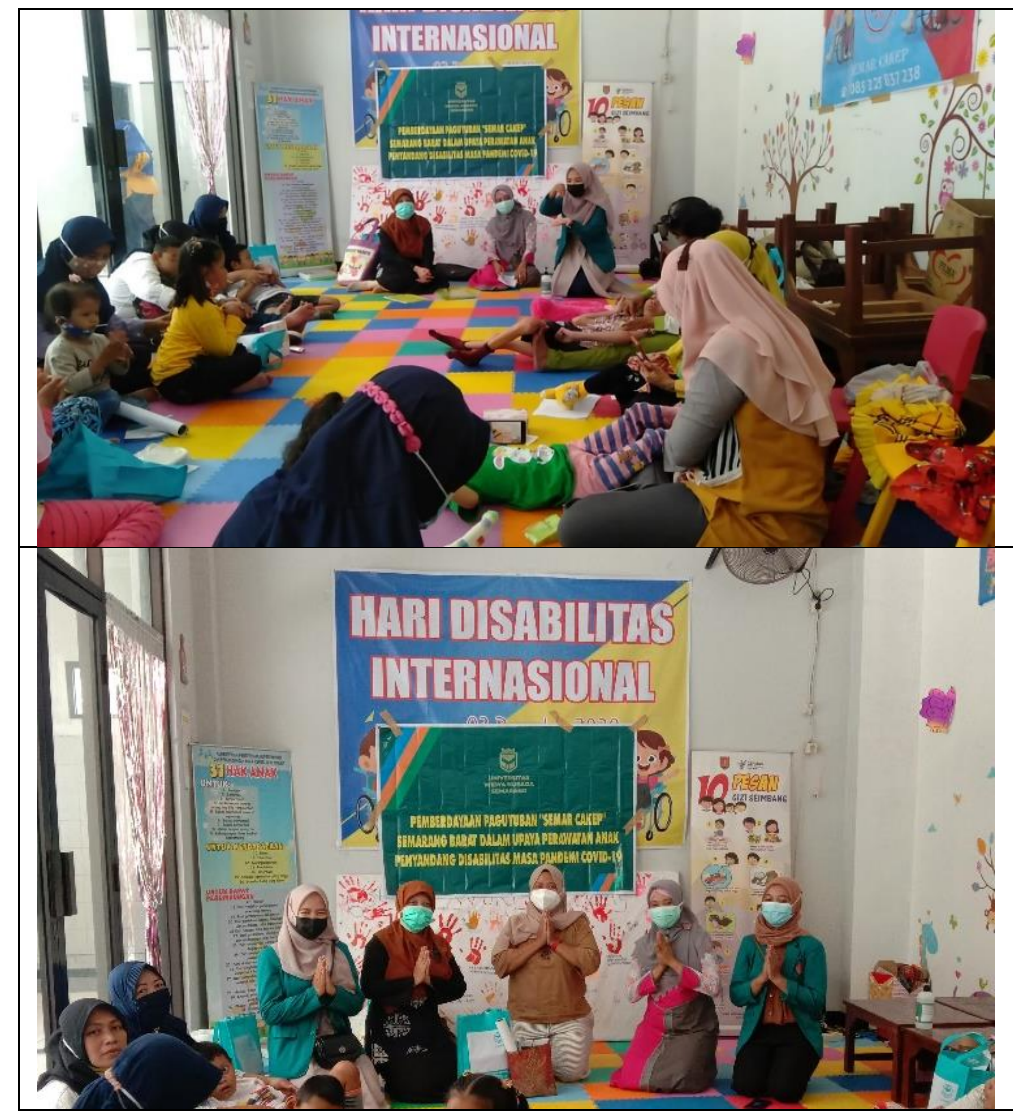

Gambar 2.2 Foto Kegiatan PKM

\section{KESIMPULAN}

Kegiatan PKM bertujuan meningkatkan pengetahuan pengurus Paguyuban Peduli Penyandang Disabilitas SEMAR CAKEP tentang perawatan anak penyandang disabilitas di masa pandemi COVID-19. Peningkatan upaya promotif dan preventif sebagai upaya deteksi dini pencegahan anak penyandang disabilitas terpapar COVID-19. Keberadaan pendamping bagi anak berkebutuhan khusus memiliki makna yang berarti bagi proses perlindungan dan tumbuh kembangnya. Evaluasi dari kegiatan PKM ini, pengurus paguyuban "SEMAR CAKEP" yang memiliki pengetahuan tinggi sebanyak 10 orang (91\%) dan yang memiliki pengetahuan rendah sebanyak 1 orang (9\%). Diharapkan dengan implementasi ini, pengurus paguyuban peduli penyandang disabilitas SEMAR CAKEP bisa menerapkan dan memberikan informasi kepada orang tua dalam perawatan anak penyandang disabilitas di masa pandemi COVID-19.

\section{DAFTAR PUSTAKA}

Afifah, W., \& Hadi, S. (2018). Pengaturan Hak Pendidikan Disabilitas (sebagai persiapan penerapan teknologi berkemanusiaan). Prosiding SEMATEKSOS 3, 0(5), 272-280. https: / /doi.org/10.12962/j23546026.y2018i5.4446

Courtenay, K., \& Perera, B. (2020). COVID-19 and people with intellectual disability: Impacts of a pandemic. Irish Journal of Psychological Medicine, 37(3), 231-236. https://doi.org/10.1017/ipm.2020.45

DirJend Kementerian Sosial. Pedoman Perlindungan Kesehatan dan Dukungan 
psikososial Terhadap Penyandang Disabilitas di wabah COVID-19 di Lingkungan Balai Besar / Balai/ Loka Disabilitas Lembaga Kesejahteraan Sosial (LKS) Disabilitas, dan Lembaga Lainnya. , (2020).

Kementerian Pemberdayaan Perempuan dan Perlindungan Anak, R. (2013). Panduan Penanganan Anak Berkebutuhan Khusus Bagi Pendamping.

Kusumah, M. (2017). Pengalaman ibu dalam merawat anak cerebal palsy di kabupaten Sumedang. Jurnal Sehat Masada, X(2), 162-178.

Prihati, D. R., Wirawati, M. K., \& Supriyanti, E. (2020). Analisis Pengetahuan Dan Perilaku Masyarakat Di Kelurahan Baru Kotawaringin Barat Tentang Covid 19. Malahayati Nursing Journal, 2(4), 780-790. https: / /doi.org/10.33024/manuju.v2i4.3073

Quyumi, E., \& Alimansur, M. (2020). Peningkatan Pengetahuan Tentang New Normal Pada Kelompok Disabilitas. Jurnal IDAMAN, 4(2), 95-102. Retrieved from https://ojs.poltekkesmalang.ac.id/index.php/idaman/article/view/2010

Radissa, V. et al. (2020). Pemenuhan Kebutuhan Dasar Penyandang Disabilitas Pada Masa Pandemi COVID-19. (August). https: / /doi.org/10.24198/focus.v3i1.28735

Sulastri, S. (2018). Pengaruh pendidikan kesehatan terhadap sikap dan perilaku dalam memelihara personal hygiene gigi dan mulut pada anak usia sekolah di SD Negeri Payung. Care : Jurnal Ilmiah Ilmu Kesehatan, 6(1), 92. https://doi.org/10.33366/cr.v6i1.786

Undang-Undang, R. (2016). Undang- Undang Republik Indonesia Nomor 8 Tahun 2016 Tentang Penyandang Disabilitas. 